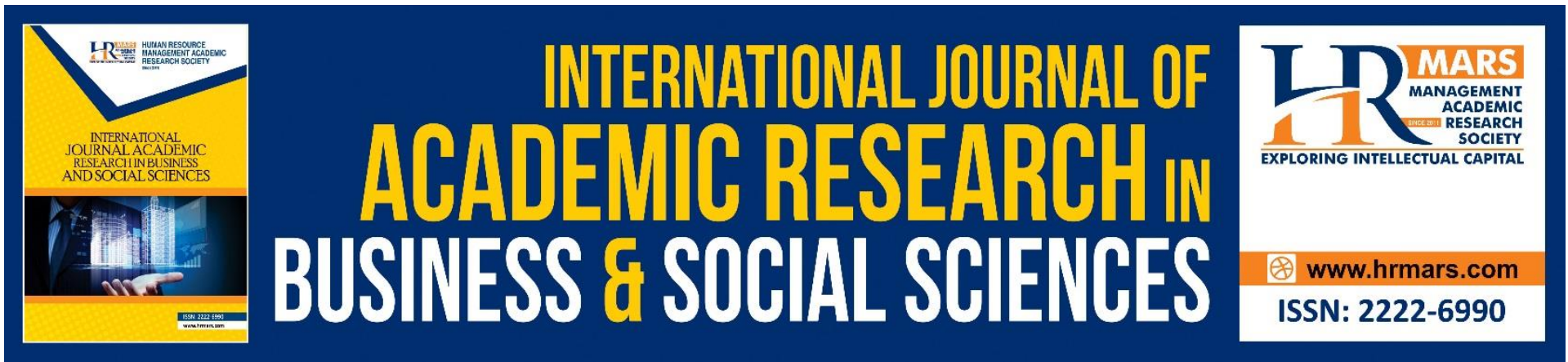

\title{
Measuring Recreational Value Using Travel Cost Method (TCM): A Number of Issues and Limitations
}

Fauziah Che Leh, Farah Zulaikha Mokhtar, Norimah Rameli \& Kamarul Ismail

To Link this Article: http://dx.doi.org/10.6007/IJARBSS/v8-i10/5306 DOI: $10.6007 /$ IJARBSS/v8-i10/5306

Received: 23 Sept 2018, Revised: 17 Oct 2018, Accepted: 30 Oct 2018

Published Online: 04 Nov 2018

In-Text Citation: (Leh, Mokhtar, Rameli, \& Ismail, 2018)

To Cite this Article: Leh, F. C., Mokhtar, F. Z., Rameli, N., \& Ismail, K. (2018). Measuring Recreational Value Using Travel Cost Method (TCM): A Number of Issues and Limitations. International Journal of Academic Research in Business and Social Sciences, 8(10), 1381-1396.

\section{Copyright: (C) 2018 The Author(s)}

Published by Human Resource Management Academic Research Society (www.hrmars.com)

This article is published under the Creative Commons Attribution (CC BY 4.0) license. Anyone may reproduce, distribute, translate and create derivative works of this article (for both commercial and non-commercial purposes), subject to full attribution to the original publication and authors. The full terms of this license may be seen

at: http://creativecommons.org/licences/by/4.0/legalcode

Vol. 8, No. 10, 2018, Pg. 1381 - 1396

Full Terms \& Conditions of access and use can be found at http://hrmars.com/index.php/pages/detail/publication-ethics 


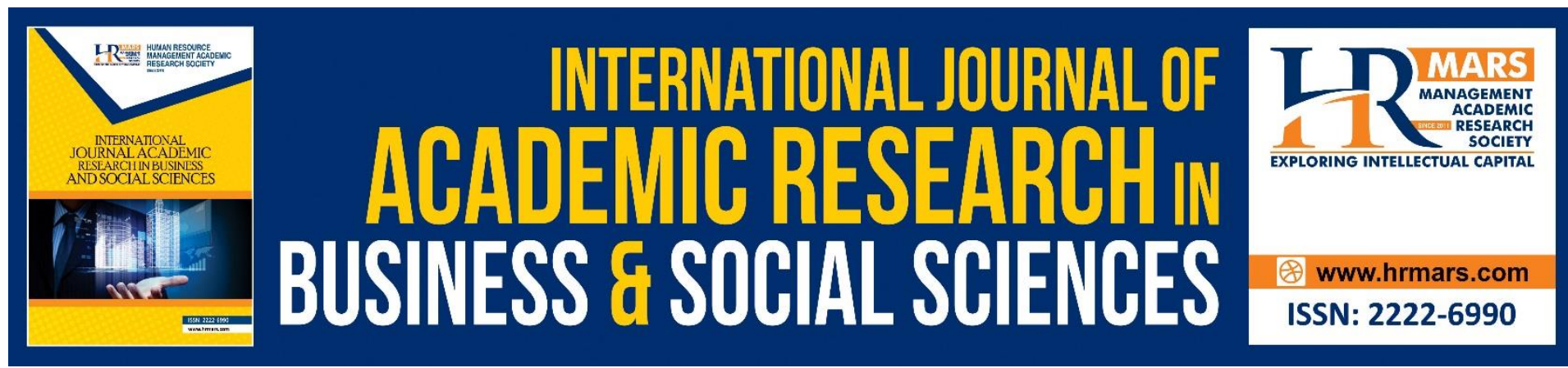

\section{Measuring Recreational Value Using Travel Cost Method (TCM): A Number of Issues and Limitations}

\section{Fauziah Che Leh, Farah Zulaikha Mokhtar, Norimah Rameli \& Kamarul Ismail}

Department of Geography and Environment, Faculty of Human Sciences, Universiti Pendidikan Sultan Idris, 35900 Tanjong Malim, Perak, Malaysia

Email: fauziah@fsk.upsi.edu.my

\section{Abstract}

This article aims to explain on how the concept of economic value assessment using Travel Cost Method (TCM) can be applied to recreational based tourism locations. By using the Travel Cost Method (TCM) approach, the economic value of a tourism location can be determined even though the attributes of that tourism site are based on recreational features. The concept of economic determination of a tourism location based on Travel Cost Method (TCM) is by the use of individual's travel cost data as a proxy for the recreational value of that tourist location. Consumers' willingness to pay (WTP) for the cost to visit the recreation area is able to show the economic value and importance of a tourism location. The reason is because visitors have to spend money to pay for the costs of travel such as fuel, tolls, parking and the costs during the stay in recreational centre such as accommodation, food and ticket prices should also be considered. However, economic value assessment using Travel Cost Method (TCM) comes with certain issues and limitations. Therefore, this article also discusses the issues and limitations in applying economic value assessment of a tourist location based on Travel Cost Method (TCM).

Keywords: Economic Value, Travel Cost Method (TCM), Recreation Area, Recreation Value

\section{Introduction}

Despite the high targets set in the 11th Malaysia Plan regarding the development of ecotourism sector, it is discovered that few studies have been conducted in relation to economic determination of ecotourism location based on a comprehensive travel cost found so far. Therefore, this article seeks to strengthen the environmental economic valuation method through the existing Travel Cost Method (TCM) technique combined with multipurpose and multi-destination trip elements as additional variables. These two elements are expected to have an impact on the results of environmental economic valuation involving ecotourism products. The section followed explains the definition of some of the key concepts in writing this article; definitions of value, economic value and Travel Cost Method (TCM) and to suggest the limitations of using TCM in order to provide understanding and to determine the scope of TCM application studies. 


\section{Definitions of Value}

Value is something that is believed to be true and encourages an individual to create it in reality. Values are important and are often become the key measurement indicators for goods and services. Value is often associated with the concept of 'price' by society. The definition of value according to Spash et al., (2005), is an item that guides individuals to weigh and choose alternative decision makers in certain social situations. Spash et al., (2005), believes that human personality is formed and rooted in the aspect of historical values. Human acceptance of values is not done passively but creatively and actively.

Dynamically, values are learned from social products and are gradually internalised by individuals and accepted as mutual belonging to their groups. Values are relatively stable conceptual standards, which explicitly or implicitly guide individuals in determining goals to be achieved and activities in order to meet psychological needs. From the definitions of value suggested by the experts, it can be concluded that value is something that is used as a guide in considering the decision to be taken later. Value is something of an abstract nature as it covers someone's thoughts. Assessment by one individual is not necessarily similar with other individuals.

While economic value is one of the various values that underlie the actions of a person or a group of people on the basis of consideration whether or not there is financial gain as a result of their actions. This economic value has a significant difference from artistic value. The environment also has an amount of economic values. Raphael and Molina (2007) describes total economic value (TEV) as a method of incorporating direct use and passive use of the environment into the overall economic framework. However, according to Young (2005), environmental economic values such as heritage value, existential value and the value of an environmental entity are difficult to be determined based on the market price mechanism due to different unique features of the environment and which do not resemble one another even of the same type. Market prices are derived based on market-pricing mechanisms by the demand and supply quantity in the market space cycle. Environmental economists assess using alternative methods of pricing the environmental entities and subsequently assess the benefits and costs from the assessment (Fuguitt and Wilcox, 1999). Environmental economic assessment is important as all costs and benefits from the environment need to be understood and considered by policy makers, decision makers and developers in making decisions that will have an impact on the environmental entity. The method used by economists in environmental assessment is by using environmental assessment methods such as Travel Cost Method (TCM).

Travel Cost Method is a quantitative assessment method used intensively by valuers all over the world as a method of measuring economic benefits of a recreational centre area such as parks, forests and wildlife sanctuaries (Mitchell and Carson, 1989). The concept of TCM is by using individual's travel cost data as a proxy for the recreational value of an area (Turner et al., 2008). The basis of this method applies the consumers' willingness to pay (WTP) concept for the cost of visiting a recreational area (Turner et al., 2008). Visitors have to spend some money to pay for the related costs such as travel costs like fuel, tolls, parking and the costs during the stay at the recreational centre such as accommodation, food and ticket prices should also be taken into account. Visitors' frequency of trips is also an important basis in measuring the economic value of a tourist location. The frequency of trips is influenced by some of individual intrinsic factors such as motivation and experience (Pearce, 2005). These two key fundamentals constitute the demand curve of visitors. However, this method does not take into account the elements of multi-purpose trip and multi-destination trip made by 
tourists as part of the existing TCM method for measuring the value of environmental economy.

Multiple-purpose trip refers to individuals travelling to a place due to some factors or reasons (Menkhaus \& Lober, 1995) and multi-destination trip refers to tourists visiting to more than one specific tourist area. As for multi-purpose trip, it is important to differentiate the type of visitors visiting a location. Only individual travel cost of pure visitors and meanderers category should be taken into account (Clough \& Meister, 1991). Pure travellers are visitors who benefit solely from the trip to a tourist location, while meanderers are those who benefit from travelling in other locations and tourist locations that they visit. As for multidestination trip, the amount of values spent by a traveller at several locations on every visit made should be calculated. Although theoretically, there has been no official method accepted in allocating the costs but this aspect should not be taken lightly in influencing the economic value of a tourist location (Beal, 1995). Smith (1971) suggests that only the cost of travel from the previous tourist location is to be taken into consideration (Beal, 1995). However, this would neglect the motivation behind the trip and result in inaccurate allocation especially for international travellers when visiting several locations during the holidays which is consisted of several days or weeks. In this situation, the first tourism location visited by tourists will result in the highest allocation of travel costs, even though the first site may not be the main reason during the travel.

Another suggestion is to divide the cost for various tourism locations by taking into account the time allocated for each location (Beal, 1995). Unfortunately, this approach does not take into account visitors' strength, excitement and satisfaction while visiting the related tourism locations. Some activities in certain tourism locations may require longer period of time while others may require less time allocation. However, the excitement and enjoyment experienced at a tourist location are not necessarily shown by the time spent (Beardsley, 1971; Clough and Meister, 1991; Font, 2000; Haspel and Johnson, 1982; Mendelsohn and Hof, 1992). A subtantial amount of studies have also touched on the issue of time cost (Beal, 1995; Bockstael, Strand, and Hanemann, 1987; McConnell, 1992; Kenneth E. McConnell and Strand, 1981; McKean, Johnson and Walsh, 1995; Shaw, 1992; Smith, Desvousges and McGivney, 1983). It is believed that the time spent at a tourism location is a cost to visitors and by being in this tourism location, tourists will spend some money to get what they desire. In other words, the opportunity to earn money is sacrificed to enjoy the recreational activities at a tourism location. Although, there are several issues involving TCM, it is one of the most suitable techniques so far for assessing recreational environmental assets. Therefore, this article aims to strengthen the existing TCM method by adding in measurement elements that involve multi-purpose trip and multi-destination trip practised by tourists at recreation-based tourism locations.

The best approach to assessing environmental assets is to use environmental economic assessment technique on non-market-based products. Travel Cost Method (TCM), Contingent Valuation Method (CVM), Choice Modelling (CM) and hedonic are among the common techniques used in environmental assessment research. Although valuing environmental assets can be carried out using other methods, but TCM is seen to be more appropriate because the environment is a non-market-based asset especially in the tourism industry that indirectly contributes to business income. While CVM is more suitable for things with aesthetical features.

The conceptual definition of Travel Cost Method refers to the basic premise of TCM which involves individual's cost and time while travelling to a recreational area with 'natural 
resources' (McConnell \& Strand, 1981). Travel Cost Method as a means of economic valuation, travel cost analysis, or Clawson method is the preferred method of exposing the economic valuation used in benefit cost analysis to calculate the value of something that can not be obtained through market price (eg. national parks, beaches, ecosystems). The purpose of this method is to calculate the tourists' willingness to pay for constant price facilities. Travel Cost Method is used to estimate economic usability value related to the ecosystems or sites used for recreational purposes. This method can be used to estimate economic benefits or costs resulted from (a) a change in the cost of access to recreational sites; (b) demolition of existing recreational sites; (c) addition of new recreational sites; and (d) a change in the environmental quality of the recreational sites (McConnell and Strand, 1981).

The basic premise of Travel Cost Method is the cost of time and travel expenses incurred by individual travellers at the travel destination they are visiting. Therefore, the willingness of tourists to pay during a trip to a tourism destination can be estimated based on the number of travels the tourist make. This method is quite similar to estimating the willingness of tourists to pay according to the market price based on the quantity requested at different prices. Travel Cost Method is used to estimate the value of recreational benefits generated by a recreational centre. It assumes how many people are willing to pay to enjoy the value of a very attractive tourism destination or recreational service. It is referred to as the "revealed preference" method, as it uses actual behaviour and choices to infer values.

Travel Cost Method is quite unobtrusive, as it follows the standard economic techniques for measuring value. This method also uses information regarding actual behaviour rather than verbal responses to scenarios imaginable. It is based on the simple and reasonable assumptions that travel costs reflect the value of recreation. Most tourists living far from certain tourism destinations are less likely to visit because they have to bear higher costs especially in terms of actual travel costs and time costs. The number of trips from the zone of origin (the latest place of residence or other tourism destination visited during the trip) at different distances from the tourism location. The travel cost from each zone is used to obtain an aggregate demand curve for the trip to this tourism destination.

Other factors may affect the number of trips to tourist destinations. Individuals with higher incomes will usually travel more to their destinations of interest. If there are other tourism destinations with alternative advantages, individual travellers will travel less. Other factors that affect TCM are personal interest in the type of tourism destination and the level of experience at the recreational areas will affect the frequency of trips.

According to McConnell and Strand (1981), in order to use the Travel Cost Method, the information to be collected includes: (a) the number of trips from each origin zone (usually can be defined by the difference in postcode), (b) demographic information of the travel of individual travellers from each zone, (c) the travel cost per mile, (d) the value of time used for travel, or the time costs of the previous travel. A more complex and comprehensive application for collecting the following information:

- the accurate distance that each individual goes to the site.

- accurate travel expenses.

- the duration of the trip.

- the amount of time spent at the travel destination involved.

- other locations visited during the same trip, and the amount of time spent on each location

- Other tourism destinations that the tourists have visited (excluding this tourism destination), and the travel distance of each of the tourism location. 
- other reasons for travel (was the purpose of the travel only for visiting the tourism destinations, or for some other purposes)

- the quality of recreational experience in this tourism destination, and on other similar sites (eg., successful fishing)

- perception of the environmental quality of the site

- site features and others, substitute, site

\section{Definitions of Economic Value Assessment}

According to Clawson and Knetsh (1966), economic value assessment is made to calculate the value of a natural resource area of non-market goods. Values are important in choosing the type and quantity of recreational experiences (McConnell and Strand, 1981). Tourism areas are natural sources of non-market goods. This is due to the fact that recreational areas such as forests, lakes, beaches, hot springs are categorised as 'non-market goods' because it is difficult to calculate the values. Freeman (2003) states that travel cost calculations allow economists to figure out the values of recreational areas based on their natural resources and the values of changing resources. In addition, economic valuation offers a way of comparing various benefits and costs related to ecosystems or natural resources and measuring them in financial units (Pagiola, Ritter and Bishop, 2004). Economic valuation of an ecosystem or natural resources area is very important in measuring the value of the area. One of the ways to valuate natural resources is by using Travel Cost Method (TCM) (refer to the formula). TCM is used to valuate recreational areas such as national parks and conservation areas, sporting locations (hunting and fishing), archaeological and cultural areas such as museums, and other natural resources such as beaches, forests and hot springs.

\section{Economic Value Assessment of Natural Resources (non-market goods)}

Tourism and recreation that involve natural environment have been identified as one of the major attractions in Malaysia. Economic value assessment of natural resources is crucial to encourage entrepreneurs and policy makers to provide more benefits to the short-term economy and long-term development towards the benefits that are related to recreational park users. The basic assumption of economic value is that the value of all goods can be expressed in an equivalent term of money and the value will be based on good utility contributions to humans (Eberle and Hayden, 1991). However, some studies have been conducted to identify economic value assessment for natural resources such as Travel Cost Method (Chan, 2003; Poor and Smith, 2004; Pawinee et al., 2005). The comparison of economic value assessment based on natural resources or ecotourism either local or foreign is discussed in the following section.

\section{Local Studies}

The use of TCM in assessing nature-based economy has been applied in several studies in Malaysia. Determining the economic value of a tourism area helps planners to make more effective decisions on property resource management efficiently, especially the natural resources. Norlida Hanim (1999), has used Travel Cost Method (TCM) and Contingent Valuation Method (CVM) to estimate the economic value of Taman Negara (National Park) located in Pahang Darul Makmur. This study found that consumer surplus for each individual in Taman Negara was estimated to be worth RM123.60 through the traditional approach and RM122.44 through the Gum-Martim approach (Norlida Hanim, 1999). TCM aims to put value on non-market items with environmental commodity characteristics by considering the 
behaviour of consumption in the relevant market, particularly the cost of services in maintaining environmental assets used as proxies for costs.

Travel Cost Method is also used to assess the environmental resource economy of Taman Pertanian Malaysia (Malaysia Agriculture Park). A study conducted by Raziah (2003) found that visitors had spent less than RM60.00 for travel-related costs towards Taman Pertanian Malaysia. The results of the study also concluded that travel cost variables show a negative sign which means that the number of trips would decrease if travel cost increases. Therefore, the increase in travel cost should be in tandem with the services provided and gain other useful benefits for visitors.

Forest reserves are also one of the important eco-tourisms in Malaysia. Economic valuation of eco-tourism such as forest reserves is very important to guide policy makers in developing policies for forest conservation. Gwee (2015) has conducted a study on economic estimation and recreational demand in the Hutan Hujan Belum Temenggor (Belum Temenggor Rainforest) complex located in Perak, Malaysia. The economic valuation on this forest reserve used the Travel Cost Method that had been modified called Truncated Poisson (TPOIS) model. The findings show that the average opportunity cost of a one-night stay time at the Forest Reserve is RM427.92 for tourists who had income loss during their trip and RM60.64 for tourist who had suffer no income loss during their trip to Hutan Hujan Belum Temenggor (Gwee, 2015). The WTP and consumer surplus for each visit to the Forest Reserve were RM586.49 and RM652. Therefore, the Hutan Hujan Belum Temenggor ecotourism had offered unreasonable prices, poor alternatives, and quite satisfactory facilities.

Local economic value assessments have been much done involving natural resources of non-market goods. As an example, the economic assessment conducted by Raziah (2003) on agricultural parks. Based on the study carried out by Raziah, it was found that the rate of trips had decreased due to the increase in travel costs. Ling (2016) in his study on the BelumTemenggor forest states that the independent variables used had significant relationship with recreational demand function variables. For example, the variables used include travel cost to recreational sites, travel cost of second-choice sites, tourists' average daily income, ethnic group (Malay) and marital status (single).

The number of trips made by visitors within a year is a dependent variable while travel expenses to urban forest, the distance from and back to home and visitors' age as independent variables. This study was conducted on an urban forest which showed a consumer surplus occurred on a visitors' trip (Shahirawati, 2010).

\section{Foreign Studies}

Limaei et al., (2013) states that the variables used in the study on the Masouleh natural forest park valuation were effective variables in the use of the park. Among the variables used were the time cost to get to the park, travel cost, age and education. The findings showed a significant relationship between the time cost and the number of visitors while the increase in visiting time resulted in a reduction in the number of visitors. Travel cost comprised of two-way (2) travel cost, admission tickets, foods and drinks, sightseeing and taking recreational pictures, boating, facilities and other costs (Silva, 2015).

One-way travel cost is calculated based on the travel distance and the type of vehicle used. While time cost is the cost of both travel time and time spent in the Pilikula lake park which is the study location. Time cost is also calculated from visitors' monthly income. The results of the study showed significant relationship towards the value of willingness to pay (WTP) which was influenced by education, gender and tourists' residential status. Fixon and 
Pangapanga (2016) point out that travel and income costs are the socio-economic factors that affect the rate of visitors' trips to Lengwe National Park, Malawi. The synthesis of literature review can be summarised as in Table 1. 


\begin{tabular}{|c|c|c|c|c|}
\hline No & Title of the Study & Justification & Variable & Result \\
\hline 1. & $\begin{array}{l}\text { Testing Significance of Multi- } \\
\text { Destination and Multi-Purpose Trip } \\
\text { Effects in a Travel Cost Method } \\
\text { Demand Model for Whale Watching } \\
\text { Trips (John Loomis, Shizuka Yorizane } \\
\text { and Douglas Larson) } 2000\end{array}$ & $\begin{array}{l}\text { The impact of destination } \\
\text { diversity is biased towards } \\
\text { consumer surplus. }\end{array}$ & $\begin{array}{l}\text { Travel cost } \\
\text { (cost of petrol for boat) } \\
\text { Other variables such as } \\
\text { income, gender and } \\
\text { socioeconomic variables. } \\
\text { The distance between change } \\
\text { of places - prices of change }\end{array}$ & $\begin{array}{l}\text { Travel cost shows a significant relationship with the cost of fuel for the } \\
\text { boat. } \\
\text { Income shows an insignificant relationship with the number of trips } \\
\text { Gender variable is significant with the primary purpose but is } \\
\text { insignificant with multi-destination. } \\
\text { The primary purpose and multi-destination for travelling to the } \\
\text { recreational area are combined to increase consumer surplus of every } \\
\text { trip. } \\
\text { By estimating consumer surplus separately from multi-destination } \\
\text { makes the total amount of recreational area benefits more accurate. }\end{array}$ \\
\hline 2. & $\begin{array}{l}\text { Allowing for Multiple-site Visitors in } \\
\text { Travel Cost Analysis ( Peter W.J. } \\
\text { Clough \& Anton D. Meister), } 1991\end{array}$ & $\begin{array}{l}\text { Only pure visitors } \\
\text { contribute to all travel } \\
\text { cost compared to transit } \\
\text { visitors and meanderers. } \\
\text { Travel cost is calculated } \\
\text { using } 3 \text { components: } \\
\text { i)the travel cost from } \\
\text { home to vacation areas } \\
\text { and divided by the time } \\
\text { spent. } \\
\text { ii) the travel cost starts on } \\
\text { the first day of travel to a } \\
\text { tourism location } \\
\text { iii) the total days spent at } \\
\text { recreational site. }\end{array}$ & $\begin{array}{l}\text { The number of trips made by } \\
\text { visitors } \\
\text { Travel cost - transport cost, } \\
\text { accommodation cost and time } \\
\text { cost. } \\
\text { Socio-economic variables - }\end{array}$ & $\begin{array}{l}\text { The value of visiting each recreational site } \\
\text { Factors - weather, regular itinerary, knowledge about the attractions in } \\
\text { the recreational area (insignificant) } \\
\text { Only socioeconomic variables (age) that are significant with travel cost. } \\
\text { Studies show that multi-destination trip can be changed which results } \\
\text { in consumer surplus to calculate the travel cost spent. }\end{array}$ \\
\hline 3. & $\begin{array}{l}\text { Net economic value of cold and } \\
\text { warm water fishing in Idaho }\end{array}$ & $\begin{array}{l}\text { Bulletin RM-11, USFS, } \\
\text { USDA, Rocky Mtn. Forest } \\
\text { and Range Exp. Station, } \\
\text { Fort Collins, CO. }\end{array}$ & $\begin{array}{l}\text { Sorg, C., J., Loomis, D. } \\
\text { Donnelly, G. Peterson, and L, } \\
\text { Nelson. Resource. “(1985), }\end{array}$ & $\begin{array}{l}\text { Tourists carrying out touristy activities at multi-destination is actually } \\
\text { setting the marginal values higher in the recreational sites measured } \\
\text { than a single destination using contingent valuation method. }\end{array}$ \\
\hline 4. & $\begin{array}{l}\text { Testing Significance of Multi- } \\
\text { destination and multi-purpose trip } \\
\text { effects in a travel cost method } \\
\text { demand model for whale watching } \\
\text { trips }\end{array}$ & $\begin{array}{l}\text { Agricultural and resource } \\
\text { economics review } 29 / 2 \\
\text { (2000) } 183-191\end{array}$ & $\begin{array}{l}\text { John Loomis, Shizuka Yorizane } \\
\text { and Douglas Larson }\end{array}$ & $\begin{array}{l}\text { The meaning of multi-purpose trip: when an individual has other } \\
\text { destinations on the way to a recreational site, nearby the recreational } \\
\text { area or on the way back home. }\end{array}$ \\
\hline
\end{tabular}




\begin{tabular}{|c|c|c|c|c|}
\hline 5. & $\begin{array}{l}\text { Recreation demand and economic } \\
\text { value: An application of travel cost } \\
\text { method for Xiamen Island }\end{array}$ & $\begin{array}{l}\text { China Economic Review } \\
15(2004) 398-406\end{array}$ & Chen W. et al. (2003) & $\begin{array}{l}\text { The study found that } 64 \% \text { of visitors who visited the beach had higher } \\
\text { education levels like college and university students. } \\
\text { While income also showed a significant relationship with the number } \\
\text { of trips made. } \\
\text { Travel cost showed negative values. } \\
\text { Studies showed that increase in travel cost would result in reduction of } \\
\text { travel rates. }\end{array}$ \\
\hline 6. & $\begin{array}{l}\text { Travel Cost Analysis of a Cultural } \\
\text { Heritage Site: The Case of Historic St. } \\
\text { Mary's City of Maryland }\end{array}$ & $\begin{array}{l}\text { Journal of Cultural } \\
\text { Economics 28:217-229 } \\
2004\end{array}$ & $\begin{array}{l}\text { P. Joan Poor And Jamie M. } \\
\text { Smith }\end{array}$ & $\begin{array}{l}\text { The study found that travel cost had a negative relationship with the } \\
\text { number of trips. } \\
\text { The total of trips had a positive relationship with income. }\end{array}$ \\
\hline 7. & $\begin{array}{l}\text { Valuing Outdoor Recreational } \\
\text { resources: A Case Study at Tman } \\
\text { Negara, Pahang Darul Makmur. }\end{array}$ & $\begin{array}{l}\text { Thesis submitted in } \\
\text { fulfilment of the } \\
\text { requirement for the } \\
\text { degree master of Science } \\
\text { in the Faculty of } \\
\text { Economics and } \\
\text { Management, UPM } \\
\text { (1999) }\end{array}$ & $\begin{array}{l}\text { Norlida Hanim binti Mohd } \\
\text { Salleh }\end{array}$ & $\begin{array}{l}\text { Used the Travel Cost Method (TCM) and Contingent Valuation Method } \\
\text { (CVM), was used to estimate the economic value of Taman Negara } \\
\text { (National Park) located in Pahang Darul Makmur. This study discovered } \\
\text { that consumer surplus for each individual in Taman Negara was } \\
\text { estimated to be worth RM123.60 through a traditional approach and } \\
\text { RM122.44 through the Gum-Martim approach (Norlida Hanim, 1999). } \\
\text { TCM aims to put value on non-market goods, namely environmental } \\
\text { commodities by considering consumerism behaviour in the relevant } \\
\text { markets, particularly the service cost in maintaining environmental } \\
\text { assets used as proxies for costs. }\end{array}$ \\
\hline 8. & $\begin{array}{l}\text { Economic valuation of } \\
\text { environmental resources at Malaysia } \\
\text { Agriculture Park }\end{array}$ & $\begin{array}{l}\text { Journal of Tropical } \\
\text { Agriculture and Food } \\
\text { Science 31(2): 261-271 } \\
\text { (2003) }\end{array}$ & Raziah, M.L. & $\begin{array}{l}\text { Visitors had spent less than RM } 60.00 \text { for travel-related costs at Taman } \\
\text { Pertanian Malaysia. The results of this study also concluded that travel } \\
\text { cost variables showed a negative sign which means trip would decrease } \\
\text { if travel cost increases. }\end{array}$ \\
\hline 9. & $\begin{array}{l}\text { An Examination of the Economic } \\
\text { Value and Recreation demand of the } \\
\text { Belum-Temenggor } \quad \text { Rainforest } \\
\text { Complex }\end{array}$ & $\begin{array}{l}\text { Thesis submitted in } \\
\text { fulfilment of the } \\
\text { requirement for the } \\
\text { degree of Doctor of } \\
\text { Philosophy (2015) }\end{array}$ & Gwee Sai Ling & $\begin{array}{l}\text { Used the modified Travel Cost Method, the Truncated Poisson (TPOIS) } \\
\text { model. The findings showed that the average opportunity cost of taking } \\
\text { a one night stay at the Forest Reserve was RM427.92 for the category } \\
\text { of tourists who made income sacrifices during the trip and RM60.64 for } \\
\text { the category of tourists who did not make income sacrifices during their } \\
\text { trip to Hutan Hujan Belum Temenggor (Gwee, 2015). The WTP and } \\
\text { consumer surplus for every visit to this Forest Reserve were RM586.49 } \\
\text { and RM652.58, respectively. }\end{array}$ \\
\hline
\end{tabular}




\section{Travel Cost Method - TCM}

One of the ways to solve the problem of calculating the value given by an individual towards a tourism spot without taking into account the weather and the check-in cost charged is the travel cost of a traveller for a destination. The amount of expenditure incurred by an individual for a trip to a tourism spot reflects his desire to spend for the area (Ortacesme, Ozkan and Karaguzel, 2002). The main purpose of TCM is to provide a values measurement for recreational sites by developing a demand 'curve' based on consumers' maximum use (Bedate et al., 2004). According to Ortacesme et al., (2002) TCM is the most frequently used indirect method for estimating the values of recreational use in natural areas. The basic equation of TCM is as follows;

$$
V=f(c, x)+\varepsilon t
$$

Where,

$$
\begin{aligned}
V & =\text { Visitation to the location } \\
c & =\text { Visitation cost } \\
x & =\text { Socioeconomic variables that significant to explain } V \\
\varepsilon t & =\text { Others factor that does not include the function but affecting } V
\end{aligned}
$$

\section{The problems that arise when using Travel Cost Method}

The TCM concept is individual's travel cost data as a proxy for recreational values by using the concept of consumers' willingness to pay (WTP) for the costs of visiting the recreational area. Therefore, there are several other elements that are not considered in the TCM concept. Bedate et al., (2004) reveals some of the problems that arise when using Travel Cost Method as follows;

\section{i. Travel Duration}

A person's travel choice is based on the values that will be gained from the travel. A travel made for part-time jobs, sports, organising are often regarded as the best travel alternatives compared to spending time on recreational travel. This means that the selection of a travel is not only assessed by the cost of a travel, but also the cost of the allocated time and alternatives for the use of the time (Bedate et al., 2004). A lot of people have a very tight working schedule and only have certain days to relax like on the weekends and public holidays. They are limited in choosing between working and recreational time, in such cases, it is possible for them to valuate time and travel as costs that involve money (Cesario and Knestch, 1966)

However, sometimes a travel is not considered as a cost but as a benefit. This situation may occur when a person chooses certain roads to enjoy the beauty of the landscapes and turn the travel into a part of the experience and recreation (Walsh et al., 1990). The travel duration is influenced by institutional, social, and economic linkages (McConnell and Strand, 1981). Therefore, the calculation of travel duration should be taken into account as it differs based on individuals' influences. 
INTERNATIONAL JOURNAL OF ACADEMIC RESEARCH IN BUSINESS AND SOCIAL SCIENCES

Vol. 8, No. 10, Oct. 2018, E-ISSN: 2222-6990 @ 2018 HRMARS

\section{ii. Multi-purpose Trip}

One of the difficulties that arise in estimating travel cost is a trip to a destination that is part of a multi-purpose destination (Bedate et al., 2004). In such cases, a difficulty arises in identifying the estimated travel cost that should be taken into the specific destination sites studied. Some of the solutions that have been made to overcome these challenges are as follows:

- Determine a part of the total cost for each destination and calculate the demand function for each of the destination (Haspel \& Johnson, 1982).

- Distribution of cost based on the time allocated by each visitor for each destination.

- Redefining the destination sites visited as a set of destinations within 'multiple-purpose travel' (Mendelsohn et al., 1992).

According to Bedate et al., (2004) none of the proposed solutions listed above can be considered as complete and accepted as a whole. The common case is that when the overall cost is divided into several destinations, the cost is reduced significantly. A person who lives close to a tourism site may spend money on the site as opposed to those who live far away or those who are on a multi-purpose trip. A study by Sorg et. al. (1985) found that multi-purpose visitors put higher marginal values on recreational sites compared to one destination using the contingent valuation method. Therefore, the multi-purpose travel element must be taken into account in the travel cost as it affects the economic value of ecotourism or natural resources.

\section{iii. Substitution Sites}

A change of recreational area is an issue that creates controversy where the recreational area existed is based on culture and history. In this regard, the types of items exhibited are unique and visitors who are interested in cultural aspects will not change the recreational place. The choice of other destinations whether or not they are cultural destinations, makes an exchange of goods as a possibility that could happen. Freeman (1993) states that an effective alternative for this study is that recreational areas should have the same characteristics. In relation to technical aspects including the rate of change of recreational area indicates two (2) unsatisfactory conditions (Caulkins et al., 1986). First, if the price is included in the model, then the risk of a correlation between price variables is high which indicates an unstable elastic measurement. Second, no price is biased even though elasticity is stable.

\section{iv. Other costs involved}

In the calculation of travel cost, there are costs that are inevitably included in the calculation. This includes transportation costs such as admission charges and parking charges. In regard to transportation costs, there is also a controversy whether the cost of fuel is only the expenses incurred or are the expenses on lubricating oils, tires and car maintenance should be included in transportation costs. Some studies have been made which state that the only costs to be calculated are based on the consumption made by travellers whether it is the fuel cost or vehicle maintenance cost while travelling. In addition, other costs that are difficult to calculate are expenses on food and facilities. 
INTERNATIONAL JOURNAL OF ACADEMIC RESEARCH IN BUSINESS AND SOCIAL SCIENCES

Vol. 8, No. 10, Oct. 2018, E-ISSN: 2222-6990 ㄷ 2018 HRMARS

This is because these additional costs are generated by travellers who travel. For example, the difference between the cost of eating at home and the dining expenses at a restaurant.

\section{v. Effects of trip duration}

The various durations of trip creates difficulties as the cost of time spent will affect travel cost. In general, visitors who travel for a long period will spend more time gaining the overall travel cost. The solution is to treat each visitor separately based on the travel duration and calculate the different demand curves for each period of time created.

\section{vi. The quality of recreational area and congestion}

The quality of a recreational area is a factor determined by an individual in selecting destinations. While congestion is a problem that affects the quality of a recreational area. A crowded recreational area happens when a large number of visitors are unable to access the recreational area. Price is less effective because visitors tend to have very small or zero entry cost. Wetzel (1977) suggests that in such cases of congestion, demand is less concerned and travel cost gives an estimate of consumers surplus below the actual value. Availability and price of goods are two important factors that are emphasized in determining the number of trips to recreational site (Ortacesme et al., 2002). Provision of good services, cultural experience, and good infrastructure is important to increase the number of visitors of the nature-based tourism. This is supported by Alberini and Longo's study (2006), that an increase in cultural experience, improvement of sites' infrastructure, and services will increase visits and will be more appreciated by visitors. Among the features that can be measured are;

a. Cultural experience at the site

b. The quality of infrastructure such as repairing the road at the site, bathrooms, rest facilities, and waste management services.

c. The quality of services such as restaurants, cafes, shops, recreational activities, and tourist information centres.

\section{vii. Not including multi-destination trip and multi-purpose trip into the existing Travel Cost Method}

Multi-destination trip is a travel made by individuals to more than one recreational areas. This variety in destinations is made by individuals while travelling, close to the recreational areas or on the way home (John L. et al., 2000). In this case, travel cost can not be interpreted as the cost paid by visitors while visiting a recreational area. Haspel and Johnson (1982) state that if observation on various destinations is done similarly as travelling to a single destination, this will result in the Travel Cost Method (TCM) measuring the benefits gained in the regular recreational area to be excessive.

In this regard, the problem associated with the diversity in travel is the diversity in the purpose of travel. Other common purposes usually involve the same destination or the destinations while on a travel. The travel cost shared between more than one tourism sites should be calculated together because otherwise, it would cause excess in estimation on the consumers' surplus values for the site 
studied (Clough \& Meister, 1991). In measuring the economic value of recreational activities outside the recreational area, analytical problems where only the demand function of multi-purpose trip is observed rather than the demand function of scientific activity. A waiver on the different travel purposes or different destinations results in a biased measurement in figuring out the difference in consumer surplus. To overcome this problem, visitors' single destination for each trip is applied as a benefit received by the visitors of multi-destination. Gum \& Martin (1957) proposes to identify the shared costs for each destination. For example, the travel cost is calculated based on the total cost spent on every location or the total travel cost is divided by the time duration spent on every destination.

TCM is one of the approaches to non-market assessments, that is to place monetary value on goods that are not purchased and sold in the regular market, such as cultural heritage and cultural heritage conservation sites (Alberini \& Longo, 2006). Therefore, TCM is suitable for measuring natural resources-based tourism.

\section{Conclusion}

This article has discussed the key variables of Travel Cost Method as an attempt to calculate the value of recreation by taking examples of local and foreign studies as a focus of discussion. The focus of the discussion of this article was also on the issues and limitations in applying Travel Cost Method in the research conducted by scholars in and outside the country. Research on environmental economic valuation is important as all economic costs and benefits from the environment need to be understood and accounted for by policy makers, decision makers and developers when making any decisions that may have an impact on environmental entity.

\section{Acknowledgement}

This article is supported by funding from Top Down KPT Fundamental Grant, Universiti Pendidikan Sultan Idris (Code: 2016-0217-106-41).

\section{Corresponding Author}

Associate Professor Dr. Fauziah Che Leh

Department of Geography and Environment, Faculty of Human Sciences, Universiti Pendidikan Sultan Idris, 35900 Tanjong Malim, Perak, Malaysia.

Email: fauziah@fsk.upsi.edu.my

\section{References}

Abildtrup, J., Garcia, S., \& Tu, G. (2013). Stated preferences of French citizens for urban green spaces and forest: A discrete choice experiment on residential location choice.

Asafu-Adjaye, J. (2005). Environmental Economics for Non-economicsts: Techniques and Policies for Techniques and Policies for Sustainable Development. Second Edition. Singapore: World Scientific Publishing Co. Pte. Ltd. 
INTERNATIONAL JOURNAL OF ACADEMIC RESEARCH IN BUSINESS AND SOCIAL SCIENCES

Vol. 8, No. 10, Oct. 2018, E-ISSN: 2222-6990 ㄷ 2018 HRMARS

Bedate, A., Herrero, L.C. \& Sanz, J.A. (2004). Economic valuation of the cultural heritage: application to four case studies in Spain. Journal of Cultural Heritage, 5, 101-111.

Chen, W., Hong, H., Zhang, L., Y., Zhang, L., Hou, X. \& Raymond, M. (2004). China Economic Review 15, 398-406.

Clough, P. J., \& Meister, A. D. (1991). Allowing for Multiple-site Visitors in Travel Cost Analysis. Journal of Environmental Management, 32, 115-125.

Fauziah Che Leh. (2010). Keberkesanan, Kepelbagaian dan Masa Depan Taman Rekreasi Kolam Air Panas (TRAP) di Negeri Perak sebagai destinasi Pelancongan Kesihatan. Laporan Akhir Penyelidikan GPU.

Fuguitt, D. \& Wilcox, S.J. (1999). Cost benefit analysis for Public Sector Decision Makers, USA: Quarom Books.

Malaysia. (1996). Pelan Ekopelancongan Kebangsaan. Kementerian Pelancongan, Kebudayaan, Kesenian dan Pelancongan.

Malaysia. (2016). Rancangan Malaysia Ke-11 (2016-2020).

Mburu, J., Abila, R., Diafas, I., Guthiga, P., Hatfield, R., Kiragu, S. \& Ritho, C. (2012). Training Manual: Economic Valuation and Assessment https://www.zef.de/module/register/media/3465_Economic\%20Valuation\%20and\%20 Environmental\%20Assessment\%20(Training\%20Manual).pdf.

McConnell, K. E., \& Strand, I. (1981). Measuring the Cost of Time in Recreation Demand Analysis: An Application to Sport fishing. American Journal of Agricultural Economics, 63(1), 153.

McKean, J. R., Johnson, D. M., \& Walsh, R. G. (1995). Valuing time in travel cost demand analysis: An empirical investigation. Land Economics, 71(1), 96.

Mendelsohn, R., \& Hof, J. (1992). Measuring recreation values with multiple destination trips. American Journal of Agricultural Economics, 74(4), 926.

Menkhaus, S., \& Lober, D. J. (1995). International Ecotourism and the Valuation of Tropical Rainforests in Costa Rica. Journal of Environmental Management, 47, 1-10.

Mendes, I \& Proenca, I. (2005). Estimating the recreation Value of Ecosystem by Using A Travel Cost Method Approach. https://www.repository.utl.pt/bitstream/10400.5/2677/1/wp82005.pdf

Pearce, P.L. (2005). Tourist Behaviour: Themes and Conceptual Schemes. UK: Multilingual Matter Ltd. 
INTERNATIONAL JOURNAL OF ACADEMIC RESEARCH IN BUSINESS AND SOCIAL SCIENCES

Vol. 8, No. 10, Oct. 2018, E-ISSN: 2222-6990 (C) 2018 HRMARS

Raphael, M.G. \& Molina, R. (2007). Conservation of Rare or Little-Known Species: Biological, Social and Economic Considerations. USA, Island Press.

Rosniza Aznie, C.R., Mohd Azlan, A., Rozalini, R., Rosmiza, M.Z., Abdul Rahim, M.N., Mohd Fuad, M.J, \& Novel, L. (2012). Potensi tarikan ekopelancongan rekreasi di Taman Rekreasi Air Panas (TRAP) Sungai Klah, Perak. Malaysia Journal of Society and Space, 8 (7): $125-134$.

Spash, C.L., Staghl, S. \& Getzner, M. (2005). Exploring Alternatives for Environmental Valuation. London, Routledge. http://clivespash.org/eaev.pdf.

Turner, R.K, Georgiou, S. \& Fisher, B. (2008). Valuing Ecosystem Services: The Case of Multi-functional Wetlands. UK: Cromwell Press.

Zaini, H., Nurul Latifah, A.R, Ahmad, S. \& Ab Khalik, W. (2013). Determination of Hot Springs PhysicoChemical Water Quality Potentially Use For Balneotherapy. Malaysian Journal of Analytical Sciences, Vol 17 (3): $436-444$. 